\title{
Poemas de Pablo Guevara
}

Se presenta por primera vez la traducción al inglés de emblemáticos poemas de Pablo Guevara (1930-2006), célebre maestro de la poesía peruana. Fue Premio Nacional de Poesía en 1954 y Premio Copé de Poesía en 1997. Autor de Retorno a la creatura (Madrid, 1957), Los habitantes (Lima, 1965), Crónicas contra los bribones (Lima, 1967), Hotel del Cusco y otras provincias del Perú (1972, reeditado en 2003), Un iceberg llamado Poesía (Lima, 1998), La colisión, ópera marítima en 5 actos: Un iceberg llamado Poesía, En el bosque de hielos, A los ataúdes, a los ataúdes, Cariátides, Quadernas, quadernas, quadernas (Lima, 1999). Y cuatro poemarios póstumos Hospital (2006), Hacia el final (2007), Mentadas de madre (2008) y Tren bala (2009). 


\section{Mi padre, un zapatero}

Tenía un gran taller. Era parte del orbe.

Entre cueros y sueños y gritos y zarpazos,

él cantaba y cantaba o se ahogaba en la vida. Con Forero y Arteche. Siempre Forero, siempre con Bazetti y mi padre navegando en el patio y el amable licor como un reino sin fin.

Fue bueno, y yo lo supe a pesar de las ruinas que alcancé a acariciar. Fue pobre como muchos, luego creció y creció rodeado de zapatos que luego fueron botas. Gran monarca su oficio, todo creció con él: la casa y mi alcancía y esta humanidad.

Pero algo fue muriendo, lentamente al principio: su fe o su valor, los frágiles trofeos, acaso su pasión; algo se fue muriendo con esa gran constancia del que mucho ha deseado.

Y se quedó un día, retorcido en mis brazos, como una cosa usada, un zapato o un traje, raíz inolvidable quedó solo y conmigo.

Nadie estaba a su lado. Nadie.

Más allá de la alcoba, amigos y familia, qué sé yo, lo estrujaban.

Murió solo y conmigo. Nadie se acuerda de él.

De Retorno a la creatura (1957) 


\section{My Father, a Shoemaker}

He had a big workshop. It was part of the city.

Amongst leather and dreams and shouts and scrapes,

he was singing and singing or drowning in life.

With Forero and Arteche. Always Forero, always

with Bazetti and my father navigating in the patio

and the friendly liquor like an endless kingdom.

He was good, and I knew this in spite of the ruins which I caressed

He was poor like many, later he grew and I grew

surrounded by shoes that later were boots.

Great monarch his trade, everything grew with him:

the house and my money box and this humanity.

But something was dieing, slowly at the beginning:

his faith or his value, the fragile trophies, perhaps his passion;

something was dieing with that great constancy of whom much

[has desired.

And one day he was, twisted in my arms,

as a used thing, a shoe ora suit,

only remained an unforgettable root and with me.

Nobody was at his side. Nobody.

Beyond the bedroom, friends and family,

what do I know, they were draining him.

He died alone and with me. Nobody remembers him. 


\section{Dos monarcas}

Amo al pescado, el plateado monarca que se agita en mis manos. Yo lo escucho y lo miro vibrante en mis sentidos, tal vez como en las costas libres de alguna gran bahía donde no hay pescadores que sumerjan sus redes. Fabulosa materia que me intriga los ojos, dinos, ¿fue feliz este espacio de aleteos dorsales? Surcador de los sodios, ¿fue feliz este estado del ser temblando en la ansiedad, pero que nunca supe si es que huía o partía hacia costas o límites? Oh, habitante del mar, - otro reino que es el mío- oh, querido, necesito saberlo. Hoy estamos cogidos. Y tú extrañas el mar. Y yo extraño el amor.

[Si sonara el amor

extenso como el mar. Oh, querido.

De Retorno a la creatura (Madrid, 1957)

\section{Two Monarchs}

I love the fish, the silver monarch that shakes in my hands. I listen to it and vibrantly watch it in my senses, perhaps like the free coasts of some great bay where there are no fisherman that cast their nets. Fabulous material that intrigues the eyes, tell us, was it happy this space of dorsal fin flapping? Furrower of sodium, was it happy this state of being trembling in nervousness, but never knowing if you were fleeing or leaving towards coasts or limits? Oh, inhabitant of the sea, -another kingdom which is mine- oh, beloved, I need to know. Today we are caught. And you miss the sea. And I miss love. If love would sound vast as the sea. Oh, beloved. 


\section{Canto XI}

\section{Las tortugas}

Ajenas a la vida de la justicia y la injusticia y bajo los cielos rojos las tortugas pasan con su casa de mil lados a cuestas...

Pasan, ignoradas de los hombres, las arrugadas que nunca estuvieron presentes en los asesinatos; en tanta noche humana son la imagen feliz de polícromos palacios y cabañas que nunca han hecho sombra a la existencia; pasean, comen, procrean, van a dormir, en las concavidades de las playas calientes escuchan la voz [de palmeras, sueñan.

De Los habitantes (Lima, 1963)

\section{Canto XI}

\section{The Turtles}

Not included in the life of justice and injustice and under the red skies the turtles go by with their houses of a thousand sides on their back...

They go by, ignored by men, the wrinkles that never were present in the murders; in so many a human night they are the happy image of polychrome palaces and cabins that never have shadowed existence; they stroll, eat, procreate, go to sleep, in the concavities of the hot beaches they listen to the voice of palm trees and dream.

Translated by Zachary Payne 